\title{
Affinity towards Entrepreneurship among Undergraduates: A Study of Engineering and Commerce Students in Kolkata
}

\author{
Prasanta Guha
}

\begin{abstract}
Entrepreneurship has become a global phenomenon today. All countries are well concerned with this issue at hand. India has also been pretty much responsive towards the development of entrepreneurship. The effort towards building entrepreneurship has become prominent with the reflection in the creation of entrepreneurship cell in different premier educational institutions, conducting of entrepreneurship week and leading entrepreneurship workshops and the like in the different corners and parts of our country. This paper attempts to understand the notion of undergraduates towards entrepreneurship in the context of latent interests among the undergraduates in engineering and commerce students. Besides it also tries to focus on the relevant factors that play a leading role in building entrepreneurs of tomorrow in the true sense of the term.
\end{abstract}

Keywords--- Entrepreneurial Intention, Non-commerce Undergraduates, Entrepreneurial Skills

\section{INTRODUCTION}

$\mathrm{T}$ ODAY, any country's economic growth has to slot in entrepreneurship as one of the most critical factor. Entrepreneurial activities give birth of number of opportunities in the economy. Micro and small enterprises can be named for this purpose. Innovation can be geared up with the initiative of entrepreneurship. In global environment entrepreneurship has also gained importance. The term "entrepreneurship" comes from the French verb "entreprendre" and the German word "unternehmen", both means to "undertake". By Grave and Hofer in1891 defined the entrepreneurial process as involving all the functions, activities, and actions associated with perceiving of opportunities and creation of organizations to pursue them. Peter Drucker explained entrepreneurship as a practice. Entrepreneurship is a skill to make something out of nothing. An entrepreneur is a person who operates a new venture and also inherits some risks and is able to look at the environment. The great ones are ready to be laughed at and criticized in the beginning because they can see their path ahead and are too busy working towards their dream. True entrepreneurs are resourceful passionate and driven to succeed and improve. One of the appropriate definition can also be coined that it is "a force that mobilizes to met unmet market demand.”

Prasanta Guha, Assistant Professor, Future Business School, Kolkata DOI: 10.9756/BIJIEMS.8100
A flourishing economy require a greater number of youth who are capable to become entrepreneurs. They can initiate and successfully develop their own marketable or societal endeavor, and ultimately they also become innovators at their workplace. In this regard entrepreneurial education can play a key role to shape the mind of the youths to motivate and providing them require knowledge and skills that they can go for new venture. A joint initiative by Babson college (USA) and London Business School (UK) towards gauging the entrepreneurial notion among different countries (presently covering more than 100 countries) and publishing report every year starting from 1999 in the name of Global Entrepreneurship Monitor (GEM) is a notable venture in this regard. Though as per GEM India reporting 2014, 58\% of Indian adults think that entrepreneurship is a better career choice and around 66\% think that this profession enjoys high level of status and respect, still India is lagging behind it's peer countries and BRICKS nations as well. GEM reports that globally youth are more likely (1.6 times) to start a business than adults. The present study is also within the ambit of understanding the entrepreneurial intention among graduates. The paper tries to capture the factors those influence the behavioral intention towards entrepreneurship among the youth in the Indian context. It also focuses on the academic background influence viz. commerce and non-commerce.

\section{LiterATURE REVIEW}

At the time of thinking entrepreneurship, some factors will be prominent within us. One should have a dream to become entrepreneur. Apart from managerial skills some typical qualities viz. inner drive to success, decision making ability, risk taking, drive towards innovations, mentality of continuous learning etc. should be obvious [18].

In India, the path of becoming entrepreneur is also a challenge today. Family pattern may be one of the reason of obstacle. Son's occupation is followed by father's. If father is service holder, the inclination of son towards business is not very common. Even the motivation from the head of the family towards business is also not so very much expected. Besides, many cases are there where business man father wants his son or daughter should go for a job and not for a business. Many other challenges are also prominent. Arranging capital also contributes a role in this matter. The role of our education system in making entrepreneur is also in question. The curriculum design may be one of the contributory factor for making education system responsible in this regard. Besides, political, technological, social issues are also put this issue into trouble [18]. 
Demographic profile also influence entrepreneur skill. Zain et. al., [20] expressed the influence of education, age, gender and work experience too on entrepreneurship skill. Study revealed that the gender has an influence on entrepreneurial skill. Male are more prone to entrepreneurship than female business graduates. Literature also revealed that parental influence has a significant role in this regard. Students those who are from business background are more interested in entering into the entrepreneurship world than those who are not from business background [6]. Pihie [17] in his literature stated two ways of measuring entrepreneurship actual entrepreneurship (where business actually started) and entrepreneurial intention (where people intends to start business). A strong relation has been found between these two.

Unemployment is a root of many problems those exist in the economy. Different social problems are very much within the purview of unemployment. Self employment initiative can overcome lots of troubles in this relation. Beeka et.al.,[3] expressed that entrepreneurship is one of the better career option for the graduates. Liking of Employers are also changing and tending towards those graduates who have enterprising skills and able to work in difficult and challenging environment [14]. Okpara [16] thinks that creation make changes of the existing market and that will become the uniqueness of the entrepreneur. With the help of creativity and innovation entrepreneur drives the society as well as economy. These two are the major weapons to achieve success. Degree of cohesiveness in a group also contributes to entrepreneurial success[11]. Another study also revealed that Leadership, communication skills, determination and motivation have positive and direct effects on performance of an entrepreneur [1]. Study also revealed that risk attitude and locus of control have strong effect on the entry and sustainability of future entrepreneur [4]. Entrepreneurship education has a great role in building entrepreneurial skill. Many authors have pointed out the same in their study. Basu and Virick [2] expressed that students' career outlook can be changed with the former experience of entrepreneurship education. Entrepreneurship education provides the light of entrepreneurial thinking, to take responsibility and to become enterprising [7].

\section{METHODOLOGY}

The research methodology of the paper is discussed in two parts - the objectives of the study primarily and the approach for data collection and analysis thereafter.

a. The essential objectives of the study are delineated as under.

- To study the perception towards entrepreneurial intention among undergraduates

- To study the factors that influence entrepreneurial skill of an individual

b. The study has been designed and developed using a set of survey questions which have been adopted after certain changes from a quiz questionnaire on entrepreneurship skill developed by Women's Initiative for Self-Employment (available at http://vetpower.org/entrepreneurial-self-assessmentquestions/\#). The sample composition is comprised of both commerce and non commerce background undergraduates. B.Tech students of different years have been considered for non commerce background and B.B.A. students have been considered for commerce background in this regard.

The questionnaire has been created in terms of continuous rating scale starting from 0 to 5 where 0 denotes strongly disagree and 5 denotes strongly agree with the statement. The questionnaire is broadly focused on tracing out of entrepreneurship skills among undergraduates.

To analyze first objective, a total score has been computed to understand the notion towards entrepreneurship skills. Higher score will reflect the higher chance to become a successful entrepreneur. Total score has been computed based on sum up scores of all the attributes.

In the questionnaire, there are total twenty one statements which have been placed to capture the perception of under graduates. As the analysis deals with number of attributes a factor analysis has been conducted to reduce these attributes into minimum number of factors. As all the attributes have been grouped into factors, to understand the effect of factors on total score which is the determinator of the notion of entrepreneurial skill the study has been moved towards regression analysis. Data have been analysed with the help of SPSS version 21.

\section{DATA ANALYSIS AND FINDINGS}

The study analyses the view of 279 undergraduates from different backgrounds viz. B.tech and B.B.A. to understand the notion towards entrepreneurship skills. Out of total respondents 159 were male and 120 were female. Table 1 shows the gender distribution among the two streams engineering and commerce graduates. It shows that males outnumber females in both categories. The study comprises of 57 $\%$ male and $43 \%$ males among the total respondents. Out of the total respondents approx $44.80 \%$ are from engineering and $55.20 \%$ are from commerce background (see Table 1). In order to study the internal consistency and reliability of scale, Cronbach Alpha-coefficient has been computed. The scale with 21 items culminated to 0.727 alpha scores which is acceptable.

Initial analysis deals with the frequency distribution of the respondents and mean scores based on gender and background of undergraduates. Table 2 projects the mean score of undergraduates of different categories. Here mean score shows the tendency towards the entrepreneurial skill. The result shows that mean score of female engineering graduate is higher (81.12) than male engineering graduate (77.10) and on the other hand mean score of male commerce graduate (78.07) is relatively higher than female (76.00). 
Table 1: Demographic Profile

\begin{tabular}{|l|l|l|l|l|}
\hline \multirow{2}{*}{ GENDER } & STREAM & \\
\cline { 3 - 5 } \multicolumn{2}{|l|}{} & ENGG GRADUATE & $\begin{array}{l}\text { COMMERCE } \\
\text { GRADUATE }\end{array}$ & \\
\cline { 3 - 5 } & & Count & Count & TOTAL \\
\hline \multirow{2}{*}{} & MALE & 78 & 81 & 159 \\
& $(27.95 \%)$ & $(29.03 \%)$ & $(56.99 \%)$ \\
\cline { 2 - 5 } & FEMALE & 47 & 73 & 120 \\
& $(16.85 \%)$ & $((26.17 \%)$ & $(43.01 \%)$ \\
& TOTAL & $44.80 \%$ & $55.20 \%$ & $100 \%$ \\
\hline
\end{tabular}

Table 2: Mean Score

\begin{tabular}{|l|l|l|l|l|}
\hline \multirow{4}{*}{} & \multicolumn{3}{|l|}{ STREAM } \\
\cline { 2 - 5 } & \multicolumn{2}{|l|}{ ENGG GRADUATE } & \multicolumn{2}{l|}{ COMMERCE GRADUATE } \\
\cline { 2 - 5 } & GNDR & GNDR \\
\cline { 2 - 5 } & MALE & FEMALE & MALE & FEMALE \\
\cline { 2 - 5 } & Mean & Mean & Mean & Mean \\
\hline Total Score & 77.10 & 81.12 & 78.07 & 76.00 \\
\hline
\end{tabular}

Due to number of attributes a factor analysis using principle component method has been applied. KMO and
Bartlett's test gives permission for sample adequacy and score represent .739 with degree of freedom of 210 (see Table 3).

Table 3 : KMO and Bartlett's Test

\begin{tabular}{|c|c|c|}
\hline \multicolumn{2}{|c|}{ Kaiser-Meyer-Olkin Measure of Sampling Adequacy. } & .739 \\
\hline \multirow{3}{*}{ Bartlett's Test of Sphericity } & Approx. Chi-Square & 1724.906 \\
\hline & Df & 210 \\
\hline & Sig. & .000 \\
\hline
\end{tabular}

Table 4 explains the total variance explained by the factors. Twenty one attributes have been reduced to six factors. Total variance is explained by six factors is approx 59 $\%$ out of which factor one is explaining highest i.e. $21 \%$ followed by second factor $12 \%$ (approx) and lowest amount is explained by factor six i.e. 5\%(approx).

Table 4 : Total Variance Explained

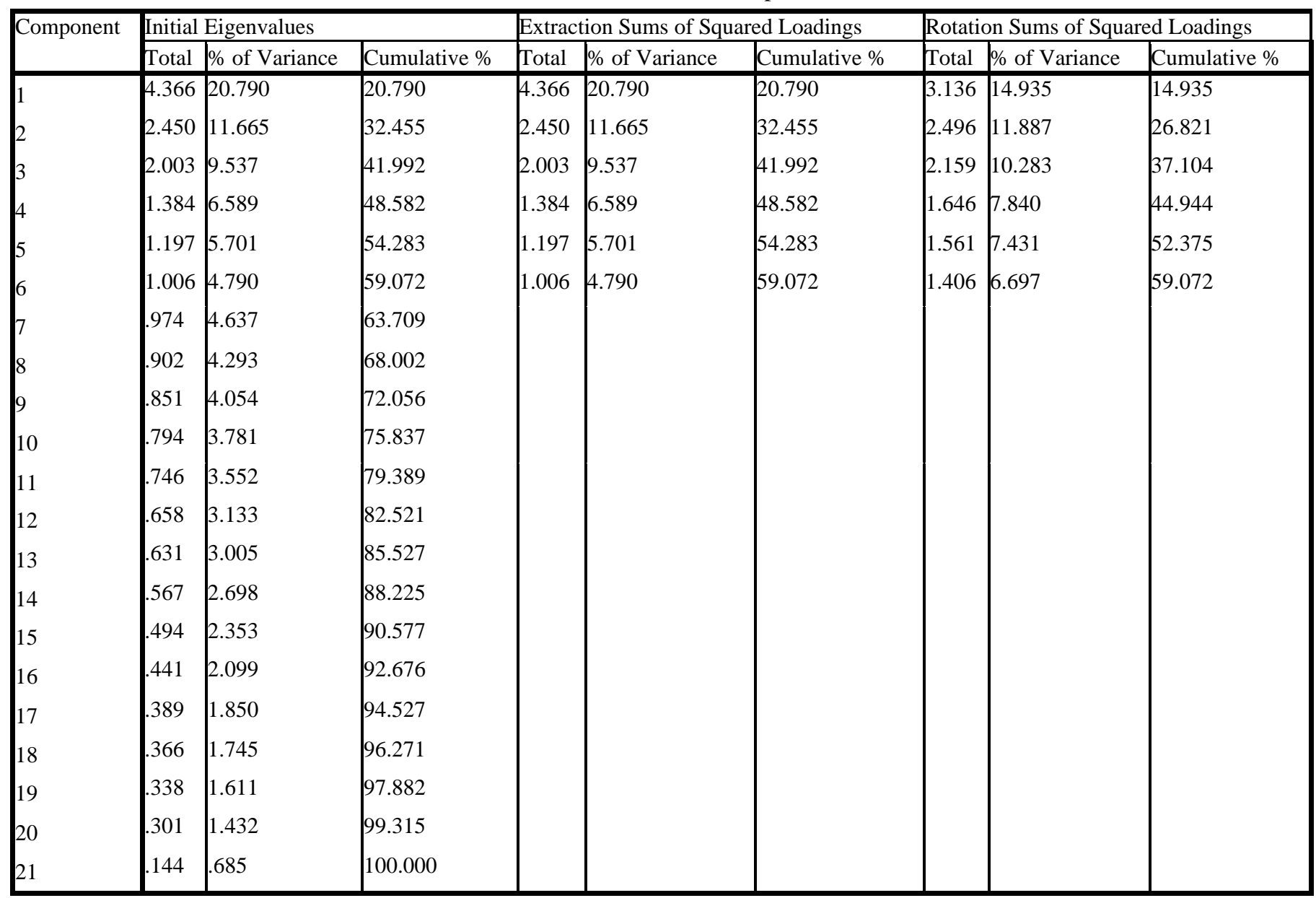

Extraction Method: Principal Component Analysis.

Table 6 (Rotated component matrix) reveals that 21 attributes loaded into 6 factors . All the six factors have been named based on closeness to the fact. Table 7 reflects the naming of factors. Hard working , high energy level, feeling proud for the successful completion of work, goal achieving orientation, controlling ownself, integrity and determination all these attributes are focusing the positive mental attitude and hence the Factor 1 has been named as "Positive Attitude".
Similarly, business experience, looking parent as role model, confidence, independence, network building can be played as a role of qualifying factor to become an good entrepreneur and therefore the Factor 2 has been named as "Qualification". Risk taking mentality, locus of control merged with self confidence has been treated as "Self Control” (i.e. Factor 3). Generating competitiveness in the mind in the entrepreneurial world not based banging on others' confidence with the 
capacity of quick decision making leads to the motion of factor naming as "Competitiveness". Financial success is mixed with financial risk. Here family support at the beginning stage plays a crucial role. Based on this view, Factor 5 has been named as "Family Patronage". Sacrificing routine job benefits and besides inviting the ambiguous situation and adapting accordingly is also a contributory factor for a successful entrepreneur and lastly the last Factor has been named as “Adaptability”(see Table 7).

Table 5: Rotated Component Matrix

\begin{tabular}{|c|c|c|c|c|c|c|}
\hline Attributes & FACTOR 1 & FACTOR 2 & FACTOR 3 & FACTOR 4 & FACTOR 5 & FACTOR 6 \\
\hline HRS_WH_NRGETK & 0.596 & 0.258 & -0.154 & -0.13 & -0.101 & -0.138 \\
\hline ENGY_WH_NRGTK & 0.573 & 0.388 & -0.083 & 0.271 & -0.228 & 0.104 \\
\hline FIN_SUC & -0.051 & 0.153 & 0.188 & -0.012 & 0.743 & -0.037 \\
\hline FAMILY_SUPPORT & 0.044 & 0.047 & -0.053 & -0.006 & 0.766 & -0.05 \\
\hline INT_LOCUS_CONTROL & 0.096 & 0.02 & 0.894 & 0.084 & 0.063 & -0.073 \\
\hline RISKTAKING & -0.38 & 0.214 & 0.499 & -0.357 & 0.02 & 0.224 \\
\hline SAC_EMPL_BENEFIT & -0.106 & 0.01 & 0.22 & -0.027 & 0.116 & -0.802 \\
\hline PRIDE_ACHMNT_NEED & 0.776 & 0.04 & 0.108 & -0.205 & 0.146 & 0.232 \\
\hline AD_EFRT_ACHMNT_NEED & 0.467 & 0.062 & 0.073 & 0.347 & 0.017 & 0.083 \\
\hline BUS_EXP & 0.049 & 0.561 & 0.079 & 0.171 & 0.266 & 0.212 \\
\hline RES_INDEPENDENT & -0.042 & 0.634 & 0.254 & -0.272 & -0.024 & -0.123 \\
\hline CNTRL_OWNSELF_INDEPENDENT & 0.706 & -0.074 & 0.183 & 0.188 & -0.048 & -0.169 \\
\hline PARENT_R_MODEL & -0.097 & 0.491 & -0.015 & -0.017 & 0.381 & 0.05 \\
\hline RES_SELF_CONFIDNCE & 0.138 & 0.024 & 0.892 & 0.097 & 0.049 & -0.134 \\
\hline ABILY_SKL_CONFIDNCE & 0.302 & 0.74 & 0.015 & 0.046 & -0.028 & -0.043 \\
\hline IGNRINGOTHR_CONFIDNCE & 0.003 & -0.028 & 0.13 & 0.767 & -0.029 & 0.06 \\
\hline INTEGRITY & 0.63 & 0.196 & 0.03 & 0.029 & 0.024 & 0.233 \\
\hline DETERMINATION & 0.5 & -0.045 & 0.015 & 0.314 & 0.042 & 0.279 \\
\hline AMB_SITUATN_ADAPT_CHANGE & 0.207 & 0.315 & 0.112 & 0.354 & 0.056 & 0.542 \\
\hline QUICK_DECISION_ADAPT_CHANGE & 0.186 & 0.51 & -0.185 & 0.535 & 0.026 & 0.156 \\
\hline PROF_NTWRK & 0.34 & 0.538 & -0.109 & 0.09 & 0.301 & 0.224 \\
\hline
\end{tabular}

Extraction Method: Principal Component Analysis.

Table 6: Factor Name

\begin{tabular}{|c|c|c|c|}
\hline ATTRIBUTES & FACTORS & ATTRIBUTES & FACTORS \\
\hline HRS_WH_NRGETK & \multirow{7}{*}{$\begin{array}{c}\text { FACTOR } 1 \\
\text { POSITIVE ATTITUDE }\end{array}$} & INT_LOCUS_CONTROL & \multirow{3}{*}{$\begin{array}{c}\text { FACTOR } 3 \\
\text { SELF CONTROL }\end{array}$} \\
\hline ENGY_WH_NRGTK & & RISKTAKING & \\
\hline PRIDE_ACHMNT_NEED & & RES_SELF_CONFIDNCE & \\
\hline AD_EFRT_ACHMNT_NEED & & IGNRINGOTHR_CONFIDNCE & FACTOR 4 \\
\hline CNTRL_OWNSELF_INDEPENDENT & & QQUICK_DECISION_ADAPT_CHANGE & COMPETITIVENESS \\
\hline INTEGRITY & & FIN_SUC & FACTOR 5 \\
\hline DETERMINATION & & FAMILY_SUPPORT & FAMILY PATRONAGE \\
\hline BUS_EXP & \multirow{4}{*}{$\begin{array}{c}\text { FACTOR } 2 \\
\text { QUALIFICATION }\end{array}$} & & \multirow{4}{*}{$\begin{array}{c}\text { FACTOR } 6 \\
\text { ADAPTABILITY }\end{array}$} \\
\hline RES_INDEPENDENT & & SAC_EMPL_BENEFIT & \\
\hline PARENT_R_MODEL & & & \\
\hline $\begin{array}{l}\text { ABILY_SKL_CONFIDNCE } \\
\text { PROF_NTWRK }\end{array}$ & & AMB_SITUATN_ADAPT_CHANGE & \\
\hline
\end{tabular}

Lastly the analysis aims to find out the impact of these factors on entrepreneurial notion by regressing these factor scores on total scores where factor scores are independent variables and total score is dependent variable.

The model summary presents that model (R square) is able to explain to the extent of $97.80 \%$ and from the ANOVA table it is evident that the model is statistically significant to explain the variables.

Table 7: Model Summary

\begin{tabular}{|l|l|l|l|l|}
\hline $\begin{array}{l}\text { Mode } \\
1\end{array}$ & & R Square & Adjusted R Square & $\begin{array}{l}\text { Std. Error } \\
\text { of the Estimate }\end{array}$ \\
\hline 1 & $.989^{\mathrm{a}}$ & .978 & .978 & 1.36183 \\
\hline
\end{tabular}

a. Predictors: (Constant), REGR factor score 6 for analysis 1, REGR factor score 5 for analysis 1, REGR factor score 4 for analysis 1 , REGR factor score 3 for analysis 1 , REGR factor score 2 for analysis 1, REGR factor score 1 for analysis 1

Table 8 : Anova $^{\mathrm{A}}$

\begin{tabular}{|l|l|l|l|l|l|}
\hline Model & $\begin{array}{l}\text { Sum } \\
\text { of Squares }\end{array}$ & df & $\begin{array}{l}\text { Mean } \\
\text { Square }\end{array}$ & F & Sig. \\
\hline 1 & $\begin{array}{l}\text { Regression } \\
122528.616\end{array}$ & 6 & 3754.769 & 2024.586 & $.000^{\mathrm{b}}$ \\
$\begin{array}{l}\text { Residual } \\
\text { Total }\end{array}$ & 504.447 & 272 & 1.855 & & \\
\hline
\end{tabular}




\section{a. Dependent Variable: TS}

b. Predictors: (Constant), REGR factor score 6 for analysis 1 , REGR factor score 5 for analysis 1 , REGR factor score 4 for analysis 1, REGR factor score 3 for analysis 1 , REGR factor score 2 for analysis 1 , REGR factor score 1 for analysis 1

Table 9 : Beta Coefficients ${ }^{\mathrm{A}}$

\begin{tabular}{|c|c|c|c|c|c|c|}
\hline \multirow{2}{*}{\multicolumn{2}{|c|}{ Model }} & \multicolumn{2}{|c|}{ Unstandardized Coefficients } & \multirow{2}{*}{$\begin{array}{l}\text { Standardized Coefficients } \\
\text { Beta }\end{array}$} & \multirow[t]{2}{*}{$\mathrm{t}$} & \multirow[t]{2}{*}{ Sig. } \\
\hline & & $\mathrm{B}$ & Std. Error & & & \\
\hline \multirow[t]{7}{*}{1} & (Constant) & 77.773 & .082 & & 953.916 & .000 \\
\hline & REGR factor score 1 for analysis 1 & 4.769 & .082 & .524 & 58.389 & .000 \\
\hline & REGR factor score 2 for analysis 1 & 5.686 & .082 & .625 & 69.619 & .000 \\
\hline & REGR factor score 3 for analysis 1 & 3.202 & .082 & .352 & 39.209 & .000 \\
\hline & REGR factor score 4 for analysis 1 & 2.106 & .082 & .231 & 25.787 & .000 \\
\hline & REGR factor score 5 for analysis 1 & 3.295 & .082 & .362 & 40.345 & .000 \\
\hline & REGR factor score 6 for analysis 1 & .640 & .082 & .070 & 7.838 & .000 \\
\hline
\end{tabular}

a. Dependent Variable: TS

Finally Table 10 projects the beta value of all the factors on the total score. All the factors are showing significant impact on the total score i.e. all factors are playing important role in building good entrepreneur. Regression equation can easily be drawn from the above table and which is as follows :

Total Score (Entrepreneurial notion) $=77.773+4.769($ Positive Attitude) + 5.686 ( Qualification) + 3.202 (Self Control) + 2.106 (Competitiveness) + 3.295 (Family Patronage) +0.640 (Adaptability)

The regression analysis made it clear that qualification which includes business experience, looking parent as role model, confidence , independence and network building in all together has great role to play in building entrepreneur followed by Positive Attitude , Family Support, Self-Control and Competitiveness. Adaptability has played relatively less stronger role in comparison to other factors.

\section{CONCLUSION}

This paper attempts to understand the notion of undergraduates towards entrepreneurship. Besides also tries to focus on the factors that influence entrepreneurial notion. Study has found that female engineers have more inclination towards entrepreneurship in comparison to male engineers. In case of commerce graduate, male proved more entrepreneurial notion than female. Further, coining Peter Drucker statement that entrepreneurship is a practice, the study concludes with the strong notion that business experience, risk taking, looking parent as a role model, ability and skill of managing business have greater role to become successful entrepreneur. Positive influence of energy, hard work, strong determination, integrity also made it clear towards creating entrepreneur. Besides, family support towards channelizing oneself into entrepreneurship, self control, quick decision making, today's sacrifice can make one individual as successful entrepreneur.

India has dynamic economy and favourable business environment which help to promote entrepreneurship. With the existence of different constraints viz, government policies, lack of entrepreneurship education etc. many forces are also facilitating to make the endeavor successful. India frantically needs proper designed curriculum for entrepreneurship education at primary as well as secondary levels along with the practical exposure.

\section{REFERENCE}

[1] Agus, A. \& Hssan, Z., "The Structural Influence of Entrepreneurial Leadership, Communication Skills, Determination and Motivation on Sales and Customer Satisfaction”, International Journal of Business and Development Studies Vol. 2, No. 1, Pp.109-130, 2010

[2] Basu, A. \& Virick, M., "Assessing entrepreneurial intentions amongst students: A comparative study”, 2008 Available: http://works.bepress.com/anuradha_basu/12/

[3] Beeka, B.H., \& Rimmington, M. "Entrepreneurship as a career option for African youths", Journal of Development entrepreneurship , 16(1): Pp145-164, 2011

[4] Caliendo, M, Frank , F \& Kritikos, A., "Personality Characteristics and the Decision to Become and Stay Self-Employed”, IZA , DP No 5566 , March,2011

[5] Enterpreneurial Self-assessment Survey available at http://vetpower.org/entrepreneurial-self-assessment-questions/\#

[6] Fatoki, O. "The Entrepreneurial Intention of Undergraduate Students in South Africa: The Influences of Entrepreneurship Education and Previous Work Experience", Mediterranean Journal of Social Sciences MCSER Publishing, Rome-Italy.Vol.5., No.7, 2014

[7] Frank, H., Korunka, C., Lueger, M., \& Mugler, J., "Entrepreneurial orientation and education in Austrian secondary schools", Journal of Small Business and Enterprise Development, 12(2), 259-273,2005

[8] Galloway, L., Kelly, S, \& Keogh, W., "Identifying entrepreneurial potential in students. National Council for Graduate entrepreneurship", Working paper series,2006

[9] Goyal, M. \& Prakash, J., "Women entrepreneurship in India-problems and prospects”, International Journal of Multidisciplinary Research Vol.1 Issue 5, Sep.2011

[10] Henley, A., "From entrepreneurial aspiration and transition to business start up: evidence from British longitudinal data", Entrepreneurship and Regional Development, 19(3): Pp.253-280, 2007

[11] Karanja,P \& Bwisa,M, H, "Factors that Influence Entrepreneurial Success among Women Groups: A Case Study of Makuyu Division” International Journal of Academic Research in Economics and Management Sciences, Vol 2 , No 1 , January 2013

[12] Kollan , B. \& Parikh, I., "A reflection of Indian Women in Entrepreneurial World", Working paper No. 2005-08-07, IIM Ahmedabad,2005

[13] Levent,T,B., Masurel, E. \& Nijkamp, P., “Gender differences in Ehtnic entrepreneurship”, $43^{\text {rd }}$ European Congress, European Regional Science Association, 2003

[14] Lourenço, F., Taylor, T.G., \& Taylor, D.W., "Integrating education for entrepreneurship in multiple faculties in "half-the-time" to enhance 
graduate entrepreneurship”, Journal of Small Business \& Enterprise Development, 20(3), Pp.503 -525, 2013

[15] Mahwshawari, D, \& Sahu , S., "Present Scenario of Entrepreneurship in India”, AISECT University Journal, Vol II, Issue IV, Sep,2013

[16] Okpara, F,O., "The value of creativity and Innovation in entrepreneurship", Journal of Asia Entrepreneurship and Sustainability, Volume III, Issue 2, 2007

[17] Pihie, Z., "Entrepreneurship as a career choice: an analysis of entrepreneurial self-efficacy and intentions of university students", European Journal of Social Sciences, 9(2): 338-349, 2009

[18] Santhi, N .\& Kumar , S, R., "Entrepreneurship Challenges and Opportunities in India”, Bonfring International Journal of Industrial Engineering and Management Science, Vol. 1, Special Issue, December 2011

[19] Shanta V, Arakeri., "Women Entrepreneurship in India”, Abhinav, Vol. 1 , Issue 3, 2012

[20] Zain, Z,M., Akram, A,M. \& Ghani,E,K., "Entrepreneurial intention among Malaysian business students”, Canadian Social Science, Vol. 6, No. 3, Pp. 34-44, 2010 